\title{
The Impacts of Cell Phone Usages on Learning Motivation:
}

\author{
What Students Say? \\ Siti Aisyah*, Mintarsih Danumihardja, Misdi Misdi \\ Universitas Swadaya Gunung Jati \\ Cirebon, Indonesia \\ *iisdudy115@gmail.com
}

\begin{abstract}
The paper attempts to describe the impact of accessing cell phone among the students of senior high schools in Cirebon. Employing survey design, the participants from several high schools in Cirebon received the questioners. From all received questionnaires, 115 were validated and sent to the further descriptive statistical analysis using the 2007 Microsoft Excel. The results revealed that more than $50 \%$ students wisely used and accessed their cell phone. In the other words, accessing cell phone had positive impacts for the students.
\end{abstract}

Keywords: cellphone, impact, learning motivation

\section{INTRODUCTION}

Cell phones is one of the results of the development of technology that has sophisticated capabilities that become the consumption of millennial generation, including high school students. Cell phones, being one of the devices that significantly change many activities, especially regarding information and communication. But in addition to information and communication, cell phones in this era are also equipped with various features, which in turn have become a necessity for its users. Call it information that used to take a long time to get it and now only requires a short time to achieve that information [1]. The cell phones accommodate various social media features such as Blackberry Messenger (BBM), WhatsApp, Line, Skype, and others.

In addition to information and communication, the entertainment side is also carried by cell phones with game features, photography, videography, and other applications. Various features in one device makes the cell phones have two sides like a blade, namely the benefits and harms, especially for high school students. The extent to which high school students use cell phones with their various functions is a potential study in exploring facts about their impact on students. However, a number of studies suggest baldy areas of investigation around the cell phone usages among the students of senior high school, especially in the context of Indonesia. Thus, in this study, researchers wanted to examine how the impact of cell phones usage among high school students in the city of Cirebon on the intensity of learning, both at school and at home [2].

\section{LITERATURE REVIEW}

Based on the Contemporary Indonesian Dictionary, a cell phones are a phone that provides features that are above and beyond the simple ability to make telephone calls [3]. Cell phones are not only a communication tool but also provide other sophisticated features, such as games, chat, Facebook and others. And that can bring a variety of things to users.

The use of cell phones has a positive influence other than for a communication tool as well as helping us to always be well connected to our friends and close relatives and family, but cell phones can also have a negative influence if used incorrectly even more with sophisticated features [2].

Intensity is a description of how long and often someone does an activity with a specific purpose [4]. Learning is a business process carried out by someone to obtain a new change in behaviour as a whole, as a result of his own experience in interactions with the environment [5-7].

\section{RESEARCH METHODOLOGY}

The study utilized survey in the data collection. From all data collected, 155 valid data were tabulated and analysed descriptively. It is important to use valid and credible methods in research [8-11] e.g. design, participant selection, and data analysis.

\section{A. Participants}

All participants were the students of senior high schools in the Cirebon. The participants were about 16-18 year old. Since the data were mainly received from the several recognized senior high schools in Cirebon, therefore, not all participants automatically regarded as participants. Their willingness and ethics were already ensured in the participant recruitment

\section{B. Procedure of Collecting Data}

From hundreds of data collected from the field, all data were manually tabulated. After that, the analysis was conducted in the 2007 Microsoft excel. 


\section{Data Analysis}

All collected data were tabulated and analysed using the 2007 Microsoft excel for the descriptive statistic outputs.

\section{FINDINGS AND DISCUSSION}

TABLE I. STUDENT ACTIVITIES IN ACCESSING THE CELlPHONE

\begin{tabular}{|l|l|l|}
\hline No & \multicolumn{1}{|c|}{ Activities } & \multicolumn{1}{|c|}{$\%$} \\
\hline 1 & For interpersonal communication & $50 \%$ \\
\hline 2 & $\begin{array}{l}\text { for access and operate whatapps, telegram, } \\
\text { For access instagram }\end{array}$ & $60 \%$ \\
\hline 3 & For chatting & $61 \%$ \\
\hline 4 & For fun & $56 \%$ \\
\hline 5 & For having business and freelance & $54 \%$ \\
\hline 6 & $\begin{array}{l}\text { Using cell phone so often in the daily For } \\
\text { communication }\end{array}$ & $46 \%$ \\
\hline 7 & For listening to music & $48 \%$ \\
\hline 8 & For access and enjoy youtube channels & $60 \%$ \\
\hline 9 & For reading articles & $46 \%$ \\
\hline 10 & For game & $37 \%$ \\
\hline 11 & For shopping & $52 \%$ \\
\hline 12 & For taking notes and learning & $53 \%$ \\
\hline 13 & For online course & $54 \%$ \\
\hline & n=155 & \\
\hline
\end{tabular}

First of all, the overall findings provided several points of cell phone usages among the students. The findings showed that the students, in facts, were rarely using their cell phones for playing games. This is interesting findings since people, nowadays; claim students were cell phone addicted for playing game. The findings suggested different facts.

Second, the average of the data showed that $50 \%$ students were able to control themselves from negative access of the cell phones for their daily activities. This is, again, reality as uncovered in the data analysis.

The highest percentage suggests that the students were actively using their cell phone for chatting, accessing Instagram and also YouTube. These mean the students were diagnosed as netizen.

The rest data indicate that the students were categorized as inactive learners as Z-generations. This means that even though they accessed and run their cell phones for their daily activities as the students, they were still unable to maximize their cell phone for their learning activities. Despite the number of percentage of accessing learning sources, e.g. reading online or offline, less than $50 \%$, the impact of the cell phone usages among the students of the senior high school in Cirebon was still not satisfying.

All findings support and provide similar research findings as revealed in the previous studies such conducted in $[5,6]$.

Finally, toward the case of the study about the impact of cell phone usages on the students' learning motivation, the overall findings suggest that there are still poor positive impacts on the student learning motivation.

\section{CONCLUSION AND SugGestion}

Even the use of the cell phone has positive impact for the students as revealed in the findings, however, the findings indicate that the students were still struggling to wisely and empowered to manage their cell phone activities for the right use in the right place. Since the study took limited participants as their samples, it is recommended to invite mote participants from the multi background demography to refer strong arguments about the cell phone usage among the students of the senior high school in the Cirebon.

\section{REFERENCES}

[1] D. Hartono, Menggunakan Smarthpone/PDA Lebih Optimal. Bandung: Informatika, 2008.

[2] J.E. Istiyanto, Pemrograman Cell phones Menggunakan SDK Android dan Hacking Android. Yogyakarta: Graha Ilmu, 2013.

[3] P. Petersalim and Y. Salim, Kamus Bahasa Indonesia Kontemporer. Jakarta: Modern English Press, 1991.

[4] A. Rismana, "Pengaruh Jejaring Sosial Terhadap Motivasi Belajar Siswa-Siswi Sekolah Menengah Pertama," Jurnal Pendidikan Geografi, vol. 3, no. 5, pp. 39-50, 2016.

[5] S. Ghifary and N. Kurnia, "Intensitas penggunaan cell phones terhadap perilaku komunikasi,” Jurnal Sosioteknologi, vol. 14, no. 2, pp. 170-178, 2015

[6] S. Slamet, Belajar Dan Faktor-Faktor Yang Mempengaruhi. Jakarta: Rineka Cipta, 2015.

[7] S. Bahri, Psikologi Belajar. Jakarta: PT Rineka Cipta, 2008

[8] M.A. Morissan, Metode Penelitian Survei. Jakarta: Prenada Media Grup, 2012

[9] M. Ali, Strategi penelitian pendidikan. Bandung: Angkasa, 1993.

[10] R. Riduwan, Belajar Mudah Penelitian untuk Guru-Karyawan dan Peneliti Pemula. Bandung: Alfabeta, 2011.

[11] S. Sugiyono, Metode Penelitian Kuantitatif, Kualitatif, dan R\&D Bandung: Alfabeta, 2012. 